\title{
Efektivitas Kewenangan Pemerintah Kota Tanjungpinang Di Bidang Kelautan Dan Perikanan Pasca Lahirnya Undang-Undang Pemerintahan Daerah
}

\author{
Ampuan Situmeang, Rufinus H. Hutauruk, Winsherly Tan*, Dian Fransisca \\ Fakultas Hukum, Universitas Internasional Batam \\ *Correspondence email: winsherly@uib.ac.id
}

\begin{abstract}
Abstrak. Tujuan dari penelitian ini yaitu pertama, menganalisis kewenangan Dinas Pertanian Pangan dan Perikanan Kota Tanjungpinang dalam melakukan pembinaan nelayan dan pengawasan kelautan pesisir setelah berlakunya Undang-Undang Nomor 23 Tahun 2014 tentang Pemerintahan Daerah. Kedua, mengidentifikasi tentang hambatan yang dihadapi Dinas Pertanian Pangan dan Perikanan Kota Tanjungpinang dalam melakukan pembinaan nelayan dan pengawasan kelautan pesisir setelah berlakunya Undang-Undang Nomor 23 Tahun 2014. Ketiga, mencari Solusi yang tepat untuk Dinas Pertanian Pangan dan Perikanan Kota Tanjungpinang. Penelitian ini menggunakan metode yuridis empiris dengan pendekatan kualitatif dan data yang digunakan adalah data sekunder. Dari hasil penelitian yang dilakukan, diperoleh hasil bahwa untuk menjamin terselenggaranya perlindungan terhadap nelayan secara optimal, sebaiknya pemerintah pusat tetap memberikan sedikit porsi bagi pemerintah Kabupaten/Kota untuk melakukan pengawasan di bidang kelautan, karena sebagian besar masyarakat nelayan masih menganggap bahwa Dinas Pertanian Pangan dan Perikanan Kota Tanjungpinang memiliki kewenangan untuk menyelesaikan permasalahanpermasalahan yang pada umumnya dihadapi para nelayan ketika melakukan kegiatan melaut.
\end{abstract}

Kata Kunci: Kelautan, Perikanan, Kota Tanjungpinang

\begin{abstract}
The purpose of this study is first, analyzing the authority of the Tanjungpinang City Food and Fisheries Department in conducting fishery development and coastal marine supervision after the enacting of Law No. 23 of 2014 on Local Government. Second, identify about the obstacles faced by the Food and Fisheries Department of Tanjungpinang City in conducting fishery development and coastal marine supervision after the enacting of Law No. 23 of 2014. Third, find the right solution for Tanjungpinang City Food and Fisheries Department. This study uses empirical juridical methods with a qualitative approach and the data used is secondary data From the results of the research conducted, it was obtained that in order to ensure the optimal protection of fishermen, the central government should still provide a small portion for the regency / city government to conduct surveillance in the marine sector, because most of the fishing community still considers that the Department of Agriculture, Food and Fisheries Tanjungpinang City has the authority to solve problems that are generally faced by fishermen when they go fishing.
\end{abstract}

Keywords: Maritime Affairs and Fisheries, Tanjung Pinang City

\section{PENDAHULUAN}

Perikanan $^{1}$ dan kelautan adalah satu dari sekian banyak bidang yang memegang peran strategis dalam pembangunan perekonomian nasional. Peran tersebut meliputi penyediaan lapangan pekerjaan terutama bagi nelayan, pembudi daya ikan, para pelaku usaha perikanan dan penyediaan kebutuhan konsumsi ikan bagi seluruh lapisan masyarakat yang berada di pelosok tanah air serta masih banyak lagi beragam manfaat lainnya. Dengan demikian, sudah semestinya pemanfaatan sumber daya perikanan harus dilakukan menggunakan cara serta peralatan tangkap yang ramah lingkungan. Pada dasarnya, pemanfaatan tersebut bertujuan untuk menjaga kelestarian sumber daya kelautan yang pada akhirnya juga berdampak pada peningkatan kesejahteraan rakyat khususnya nelayan dan pembudi daya ikan kecil, peningkatan daya saing hasil perikanan dengan negara asing yang pada akhirnya dapat meningkatkan pendapatan Negara. Keseluruhan upaya tersebut tentu saja hanya akan berjalan apabila didukung oleh peran pemerintah dan dilaksanakan secara bersama-sama, baik di tingkat pusat hingga ke daerah secara sinergis. ${ }^{2}$

Dengan luas wilayah lautan yang mencapai hampir dua per tiga (2/3) dari wilayah Indonesia, yaitu $6,32 \mathrm{~km} 2$ dan terdiri dari 17.504 pulau, sejak lama Indonesia memiliki mimpi besar menjadi poros maritim dan pusat perikanan dunia. Berbagai program telah dilakukan dalam menunjang cita-cita tersebut, salah satunya menjadi produsen ikan terbesar di dunia dengan cara memproduksi lebih dari 16 juta ton ikan dalam setiap tahunnya. Namun faktanya, produksi perikanan Indonesia saat ini hanya mencapai 10,83 juta ton per tahun. Artinya, untuk dapat disebut sebagai "pusat perikanan", masih harus mengejar ketinggalan sekitar 6 juta ton. Berdasarkan data yang peneliti peroleh melalui laman Kementerian Kelautan dan Perikanan (KKP), ditemukan bahwa seharusnya potensi lestari perikanan

${ }^{1}$ Berdasarkan Pasal 1 angka 20 UU No.7 Tahun 2016, adapun yang dimaksud dengan Perikanan adalah "semua kegiatan yang berhubungan dengan pengolahan dan pemanfaatan sumber daya ikan dan lingkungannya mulai dari praproduksi, produksi, pascaproduksi dan pengolahan sampai dengan pemasaran yang dilaksanakan dalam suatu bisnis perikanan".

${ }^{2}$ www.setkab.go.id,diakses tanggal 17 Februari 2019. 
laut Indonesia terhitung sebesar 6,4 juta ton per tahun, sementara jumlah tangkapan yang diperbolehkan hanya 5,12 juta ton per tahun.

Sampai dengan tahun 2019, pemanfaatan potensi perikanan masih berada pada level 83,98\% (delapan puluh tiga persen) dari total tangkapan ikan yang diizinkan. Akan tetapi, berdasarkan hasil pengawasan yang dilakukan masih ditemui adanya potensi penangkapan secara ilegal yang dilakukan oleh nelayan asing serta penangkapan yang tidak dilaporkan kepada lembaga yang berwenang sebesar 1,5 juta ton per tahunnya, sehingga jika diakumulasi, perikanan laut Indonesia dapat dikatogerikan "kelebihan penangkapan".

Tidak dapat dipungkiri bahwa setiap Nelayan memiliki andil yang sangat penting terhadap perkembangan perekonomian di wilayah pesisir, khususnya yang bekerja di tengah laut. Sehingga sebagai Negara yang berlandaskan hukum, berbagai kebijakan telah diciptakan untuk mewujudkan regulasi yang berpihak pada seluruh kalangan masyarakat termasuk Nelayan kecil. Dalam hal jaminan penyelenggaraan perikanan dan kelautan. Komitmen tersebut ditetapkan dalam Undang-Undang Nomor 7 Tahun 2016 tentang Perlindungan dan Pemberdayaan Nelayan, Pembudi Daya Ikan, dan Petambak Garam. Jika dilihat dari landasan filosofis yang mendasari lahirnya aturan ini, bahwa undang-undang tersebut telah disejalankan dengan landasan Negara yaitu Pancasila dan UUDNRI Tahun 1945 yang mengamanatkan bahwa:

"negara memiliki tanggung jawab untuk melindungi segenap bangsa Indonesia dan seluruh tumpah darah Indonesia dan untuk memajukan kesejahteraan umum, mencerdaskan kehidupan bangsa, serta mewujudkan keadilan sosial bagi seluruh rakyat Indonesia”.

Dengan adanya payung hukum ini, diharapkan mampu memberikan kepastian serta perlindungan hukum terhadap berbagai permasalahan yang dihadapi para nelayan kecil maupun nelayan tradisional serta pengusaha perikanan dalam kesehariannya melakukan penangkapan ikan di perairan Indonesia, karena selama ini masih adanya anggapan bahwa pemerintah kurang memperhatikan serta cenderung mengabaikan kondisi kehidupan nelayan kecil, buruh nelayan dan keluarganya. Dalam konteks yang lebih sempit, sebagai satu dari sekian banyak wilayah kepulauan di Indonesia yang juga memiliki potensi perkembangan usaha perikanan adalah Kota Tanjungpinang, yaitu ibukota dari Provinsi Kepulauan Riau. Mengingat posisi letak wilayahnya yang strategis karena terletak pada jalur perdagangan internasional dan berbatasan langsung dengan Negara Singapura, Malaysia dan Thailand, sehingga tidak heran jika produksi hasil perikanan tangkap yang diperoleh nelayan dari kota ini kerap kali di ekspor ke luar negeri dengan harga yang tidak terlalu mahal. Disamping itu, nelayan kecil dan tradisional juga berisiko mengalami kecelakaan kerja di laut dan mengalami masalah hukum lainnya karena memasuki batas wilayah perairan laut Negara seberang tanpa izin. ${ }^{3}$

Dilihat dari sisi perolehan hasil perikanan tangkapnya, Menurut pendataan yang ada pada Dinas Pertanian Pangan dan Perikanan Kota Tanjungpinang, dalam 4 (empat) tahun terakhir terdapat peningkatan jumlah perikanan tangkap, maupun baik budidaya. Hal ini terbukti pada tahun 2016, hasil tangkapan hanya mencapai angka 35.242.130 ton, akan tetapi mengalami peningkatan menjadi sebesar 50,527,682 ton pada tahun 2017. Selanjutnya capaian tahun 2018 juga tidak kalah jika dibanding dengan tahun sebelumnya, yakni sebesar 51.636.453 ton. Pada akhir 2019, sektor perikanan kembali memperoleh capaian yang luar biasa fantastis yaitu pada angka 65.711.261.400 ton. Data indikator perikanan di Kota Tanjungpinang yang peneliti peroleh juga menunjukkan hasil yang cukup membanggakan yaitu sebagaimana tercantum dalam tabel 1 sampai dengan tabel 3 berikut ini :

Tabel 1. Perkembangan Luas Areal Budidaya di Kota Tanjungpinang Tahun 2016 s.d Tahun 2019 (dalam ha)

\begin{tabular}{cccccc}
\hline No & Jenis Budidaya & Tahun 2016 (ha) & Tahun 2017 (ha) & Tahun 2018 (ha) & Tahun 2019 (ha) \\
\hline 1. & Budidaya Air Tawar & 10.5 & 10.5 & 8.5 & 49.67 \\
2. & Budidaya Air Laut & 9.5 & 9.5 & 9 & 18.05 \\
& Jumlah & 20.0 & 20.0 & 17.5 & 67.72 \\
\hline
\end{tabular}

Sumber: Dinas Pertanian Pangan dan Perikanan Kota Tanjungpinang

Tabel 2. Perkembangan Rumah Tangga Perikanan di Kota Tanjungpinang Tahun 2016 s.d Tahun 2019 (dalam ton)

\begin{tabular}{clcccc}
\hline No & Rumah Tangga Perikanan & Tahun 2016 & Tahun 2017 & Tahun 2018 & Tahun 2019 \\
\hline 1. & Penangkapan & 1531 & 1540 & 1571 & 190 \\
2. & Budidaya Air Laut & 210 & 206 & 230 & 190 \\
3. & Budidaya Air Tawar & 285 & 263 & 129 & 230 \\
4. & Pengolahan & 122 & 125 & 2120 & 255 \\
& Jumlah & 2148 & 2009 & & 2270 \\
\hline
\end{tabular}

Sumber: Dinas Pertanian Pangan dan Perikanan Kota Tanjungpinang

3 Kusnadi. Konflik Sosial Nelayan: Kemiskinan Perebutan Sumber Daya Perikanan. Jakarta: PT LKiS Pelangi Aksara, 
Ampuan Situmeang, Rufinus H. Hutauruk, Winsherly Tan dan Dian Fransisca, Efektivitas Kewenangan Pemerintah Kota Tanjungpinang Di Bidang Kelautan Dan Perikanan Pasca Lahirnya Undang-Undang Pemerintahan Daerah

Tabel 3. Perkembangan Alat Penangkapan Ikan di Kota Tanjungpinang Tahun 2016 s.d Tahun 2018

\begin{tabular}{|c|c|c|c|c|}
\hline No & Jenis Alat Tangkap & Tahun 2016 & Tahun 2017 & Tahun 2018 \\
\hline 1. & Jaring Apolo / Udang & 3112 & 3212 & 3382 \\
\hline 2. & Jaring Insang Hanyut / Gillnet & 2520 & 2567 & 2637 \\
\hline 3. & Jaring Insang Tetap & 670 & 673 & 650 \\
\hline 4. & Bubu Ikan & 1286 & 1389 & 900 \\
\hline 5. & Bubu Ketam & 9660 & 9889 & 8541 \\
\hline 6. & Sondong & 168 & 150 & 169 \\
\hline 7. & Suluh / Tombak & 198 & 200 & 185 \\
\hline 8. & Tangkul & 152 & 160 & 162 \\
\hline 9. & Kelong Pantai & 23 & 25 & 21 \\
\hline 10. & Pukat Ikan & - & - & - \\
\hline 11. & Pursesein & 2 & 6 & 9 \\
\hline 12. & Rawai & 60 & 67 & 70 \\
\hline 13. & Kelong Bilis & 37 & 40 & 42 \\
\hline 14. & Injap & 143 & 150 & 100 \\
\hline 15. & Cari Gonggong & 155 & 150 & 161 \\
\hline 16. & Pukat Teripang & 32 & 30 & 30 \\
\hline 17. & Pukat Dua & 22 & 17 & 17 \\
\hline 18. & Empang & 17 & 12 & 10 \\
\hline 19. & Pancing & 161 & 170 & 200 \\
\hline 20. & Jala & 38 & 17 & 18 \\
\hline 21. & Boukeami & 3 & 3 & 0 \\
\hline & Jumlah & 18459 & 18927 & 17304 \\
\hline
\end{tabular}

Sumber: Dinas Pertanian Pangan dan Perikanan Kota Tanjungpinang

Adanya perkembangan sektor perikanan di Kota Tanjungpinang tidak terlepas dari peran pemerintah daerah yang dilaksanakan melalui Perangkat Daerah terkait, yaitu Dinas Pertanian Pangan dan Pertanian (DP3). Sistem penyelenggaraan pemda yang dilaksanakan berdasarkan konteks otonomi daerah juga membagi sebagian porsi kepada pemerintah kabupaten/kota untuk dapat menyelenggarakan urusan pemerintahan di bidang kelautan dan perikanan (KP). Berdasarkan ketentuan Pasal 11 ayat (3) UU No.23 Tahun 2014, bidang ini merupakan urusan pemerintahan konkuren yang bersifat pilihan. Penegasan terkait kewenangan ini juga telah diatur dalam Pasal 9 ayat (4) UU No. 23 Tahun 2014 tentang Pemerintahan Daerah (atau yang juga sering disebut dengan UU Pemda) yang menyatakan bahwa "Urusan pemerintahan konkuren yang diserahkan ke Daerah menjadi dasar pelaksanaan Otonomi Daerah". Adanya pendelegasian kewenangan tersebut pada prinsipnya bertujuan untuk meningkatkan kesejahteraan masyarakat dengan cara peningkatan pelayanan, peran serta masyarakat, pemberdayaan, dan adanya peningkatan daya saing daerah. Namun dengan tetap memperhatikan prinsip keadilan, demokrasi, serta pemerataan dan yang tidak kalah penting adalah mengutamakan kearifan lokal suatu daerah dalam konteks Negara Kesatuan Republik Indonesia. Disamping itu, konsep otonomi daerah diharapkan dapat menjadikan penyelenggaraan lebih efisien dan efektif dengan tetap memperhatikan setiap aspek hubungan antara Pemerintah, baik tingkat pusat, tingkat daerah maupun antar daerah, potensi serta keberagaman setiap daerah, serta berbagai peluang serta tantangan terhadap persaingan global dalam konteks kesatuan penyelenggaraan sistem pemerintahan Negara.

Akan tetapi, lahirnya uu Pemda tersebut ternyata kian mempersempit kewenangan pemerintah kabupaten/kota di sektor kelautan dan perikanan, apabila dibandingkan dengan undang-undang sebelumnya Nomor 32 Tahun 2004. Jika dilihat dari lampiran undang-undang tersebut khususnya terkait pembagian urusan kewenangan sub urusan Kelautan dan Perikanan, dari 5 (lima) sub urusan yang ada, Pemerintah Kabupaten/Kota hanya dapat melaksanakan 3 (tiga) kewenangan saja, yaitu sebagai berikut:

a. Perikanan Tangkap , meliputi Pemberdayaan Nelayan Kecil, Pengelolaan dan penyelenggaraan tempat pelelangan ikan; dan

b. Perikanan Budidaya, meliputi Penerbitan izin usaha perikanan (IUP) di bidang pembudidayaan ikan yang usahanya dalam 1 (satu) daerah kab/kota, Pemberdayaan usaha kecil pembudidayaan ikan dan Pengelolaan pembudidaya ikan.

Padahal jika dilihat kondisi di lapangan, pasca berlakunya undang-undang Pemda tersebut, Pemerintah Kota Tanjungpinang melalui perangkat daerah yang menyelenggarakan urusan pemerintahan di bidang perikanan justru mengalami berbagai kendala dalam melakukan pembinaan dan pengawasan kepada nelayan kecil dan nelayan tradisional yang ada di wilayahnya. Kendala tersebut tidak lain disebabkan karena telah dihapuskannya sebagian kewenangan pemda kabupaten/kota antara lain pengawasan sumber daya kelautan dan perikanan, kelautan pesisir dan pulau-pulau kecil serta pengolahan dan pemasaran hasil perikanan sebagaimana telah peneliti cantumkan di atas. 
Dengan berlakunya UU Pemda yang baru, kini kewenangan tersebut telah beralih ke pemerintah provinsi dan pemerintah pusat. Secara yuridis, Pemerintah telah mengatur adanya kewajiban bagi Pemerintah Daerah untuk melakukan pengawasan dalam rangka mewujudkan perlindungan dan pemberdayaan bagi Nelayan dan Pembudidaya Ikan yang diamanatkan dalam Pasal 70 UU No.7 Tahun 2016 yang berbunyi:

(1) Untuk menjamin tercapainya tujuan Perlindungan dan Pemberdayaan Nelayan, Pembudi Daya Ikan, dan Petambak Garam, dilakukan pengawasan terhadap kinerja perencanaan dan pelaksanaan.

(2) Pengawasan sebagaimana dimaksud pada ayat (1) meliputi pemantauan,pelaporan, dan evaluasi.

(3) Pengawasan sebagaimana dimaksud pada ayat (1) dan ayat (2) dilaksanakan oleh Pemerintah Pusat dan Pemerintah Daerah sesuai dengan kewenangannya".

Hal ini tentu saja membatasi ruangan gerak pemda kabupaten/kota dalam menangani masalah yang dihadapi nelayan di daerahnya seperti Hampir setiap tahun terjadi penangkapan ikan tanpa izin (illegal fishing), kematian nelayan yang diakibatnya kecelakan pada saat melaut, minimnya upah buruh nelayan serta masih adanya praktik pinjaman bagi nelayan yang dilakukan oleh pengusaha perikanan dan belum terdaftarnya sebagian besar nelayan dalam program asuransi nelayan. Terbatasnya wilayah perairan laut yang menjadi kewenangan pemerintah kabupaten/kota juga menjadi alasan sulitnya koordinasi yang cepat dalam penanganan permasalahan tersebut. Dengan ditariknya kewenangan pemerintah Kota Tanjungpinang dalam bidang kelautan, otomatis membuat pemda tidak dapat berbuat banyak terhadap para nelayan kecil maupun buruh nelayan yang melaporkan masalahnya kepada Dinas Pertanian Pangan dan Perikanan. Sebagaimana kita ketahui, bahwa sebelumnya pada UU No.32 Tahun 2004 memang terdapat pembagian kewenangan pengelolaan dan pengawasan laut, di mana untuk jarak $0-4$ mil merupakan kewenangan kabupaten/kota, sementara untuk jarak 4-12 mil dikelola oleh provinsi, dan 12 mil ke atas merupakan kewenangan pemerintah pusat. Kebijakan ini secara otomatis telah menghapus kewenangan kabupaten/kota. Sehingga nomenklatur Dinas Kelautan dan Perikanan akhirnya berubah menjadi Dinas Perikanan saja. Politik hukum terkait kebijakan di sektor kelautan dalam UU 23/2014 pada dasarnya juga memiliki kelemahan, dimana pengalihan kewenangan Kewenangan Perikanan terhadap pemerintah Kabupaten/Kota tidak ditopang dengan anggaran yang cukup memadai. Selain itu, dengan ditariknya sebagian pegawai yang berada di bidang kelautan juga kian semakin memperlambat proses pembinaan dan pemberdayaan nelayan yang ada di wilayah kota Tanjungpinang. Kendala lain yang dihadapi Pemda sendiri adalah seringkali antar sesama pemerintah Kota Tanjungpinang dan Pemerintah Provinsi saling lempar bola dalam menindaklanjuti laporan atau pengaduan dari nelayan yang mengalami kecelakaan kerja. Hal ini sangat disayangkan dan seharusnya tidak boleh terjadi agar tidak merugikan nelayan yang ada di Kota Tanjungpinang dan juga wilayah pesisir.

\section{HASIL DAN PEMBAHASAN}

Efektivitas Pelaksanaan Kewenangan Dinas Pertanian Pangan dan Perikanan Kota Tanjungpinang dalam melakukan pembinaan nelayan dan pengawasan kelautan pesisir pasca berlakunya Undang-Undang Nomor 23 Tahun 2014 tentang Pemerintahan Daerah

Nelayan merupakan salah satu dari jenis profesi masyarakat di daerah maritim, Kota Tanjungpinang yang memiliki peran dan pengaruh strategis pada bidang kelautan dan perikanan. Peran tersebut meliputi penyediaan ketahanan pangan yang berasal dari sumberdaya perikanan/kelautan, menyediakan lapangan kerja bagi pengusaha perikanan, nelayan itu sendiri bahkan buruh nelayan, keberlanjutan hasil sumber daya, geopolitik, serta peran dalam upaya peningkatan devisa. Profesi nelayan bukan lagi hal yang baru di Negara kita, bahkan sudah sejak lama kita mengenal penggalan lagu "nenek moyangku seorang pelaut,gemar mengarung luas samudera, menempuh badai, menerjang musuh". Sehingga sudah sewajarnya pemerintah lebih memperhatikan lagi setiap kegiatan yang berkaitan dengan aktivitas para nelayan yang rentan dengan risiko berupa kecelakaan di perairan laut, bahkan kehilangan nyawa karena terbawa arus, dan sebagainya.

Bentuk perhatian tersebut semakin hari terus ditingkatkan melalui berbagai regulasi yang mengatur tentang perlindungan dan pemberdayaan nelayan sebagaimana diatur dalam UU No. 7 Tahun 2016. Dalam aturan tersebut, telah ditetapkan wewenang dan tanggungjawab stakeholder untuk memberikan pembinaan serta pengawasan terhadap para nelayan. Ketentuan pasal tersebut diatur dalam Pasal 70 UU No.7 Tahun 2016 yang menyatakan bahwa:

(1) Untuk menjamin tercapainya tujuan Perlindungan dan Pemberdayaan Nelayan, Pembudi Daya Ikan, dan Petambak Garam, dilakukan pengawasan terhadap kinerja perencanaan dan pelaksanaan.

(2) Pengawasan sebagaimana dimaksud pada ayat (1) dilaksanakan oleh Pemerintah Pusat dan Pemerintah Daerah sesuai dengan kewenangannya". 
Pengawasan yang dimaksudkan dalam rumusan di atas memiliki beragam pengertian. Dalam $K B B I$, pengawasan merupakan suatu kata benda yang berasal dari kata dasar "awas". Sedangkan menurut ensiklopedia, pengawasan berarti "penilaian" atau "penjagaan". Pada umumnya, pengawasan dapat terbagi menjadi 2 (dua) bentuk, yaitu:

a. Preventif, contohnya yaitu kegiatan pengawasan yang dilakukan terhadap perda dan perkada terkait hal tertentu yang akan berlaku setelah adanya pengarahan dari pejabat yang berwenang; dan

b. Represif, contohnya yaitu pengawasan yang dilakukan dalam bentuk pembatalan atau penangguhan perda atau perkada yang dilakukan oleh pejabat yang berwenang.

Selain definisi tersebut di atas, beberapa ahli juga telah memberikan berbagai pengertian dari pengawasan. Mengutip pendapat Victor Situmorang dan Jusuf Juhir yang menyatakan bahwa Pengawasan adalah:

\section{"Bentuk upaya dan tindakan dalam rangka untuk mengetahui sejauh mana pelaksanaan tugas yang dilaksanakan menurut ketentuan dan sasaran yang ingin dicapai."}

Selanjutnya ada pula pengertian yang dikemukakan oleh Fayol, yang menyebutkan bahwa Pengawasan adalah Pengujian terhadap suatu aktivias pekerjaan, apakah berjalan sesuai dengan rencana yang telah ditetapkan berdasarkan instruksi yang sudah digariskan. Sedikit berbeda dari pengertian yang ada di atas, Dale membatasi bahwa sesungguhnya pengawasan tidak hanya melihat sesuatu secara seksama dan setiap hal yang diawasi disampaikan dalam bentuk laporan, akan tetapi juga dapat diartikan sebagai upaya meluruskan serta memperbaiki sesuatu hal agar dapat mencapai tujuan yang telah direncanakan sebelumnya.

Dalam kaitannya dengan pembinaan dan pengawasan terhadap nelayan, pemerintah telah membagi porsi kewenangan antara pemerintah tingkat pusat, pemprov serta pemerintah daerah kabupaten atau kota. Hal ini dimaksudkan karena sejak adanya desentralisasi (otonomi daerah), pemerintah daerah juga berhak untuk mengurus rumah tangganya sendiri. Kelautan dan Perikanan merupakan salah satu urusan pemerintahan pilihan yang dapat dilaksanakan oleh pemerintah kabupaten maupun pemerintah kota. Namun pasca berlakunya UU No. 23 Tahun 2014 tentang Pemerintahan Daerah, urusan yang terkait dengan kelautan tidak lagi menjadi ranahnya pemerintah kabupaten/kota. Namun sebagian beralih kepada pemprov dan juga pemerintah pusat. Penjelasan ini juga diperkuat oleh wawancara yang peneliti lakukan kepada Kepala Bidang Kelautan dan Pengawasan yang mana dari hasil penjelasannya diperoleh informasi bahwa terhadap sektor kelautan dan perikanan di daerah memang didominasi oleh pemerintah provinsi kepri, dimana sebagai daerah kepulauan yang memiliki 7 (tujuh) kabupaten maupun kota yang meliputi Kota Tg.Pinang, Kota Batam, Kab.Natuna, Kab. Lingga, Kab.Karimun serta Kab.Kepulauan Anambas. Setelah berlakunya UU No. 23 Tahun 2014, Dinas Kelautan dan Perikanan Prov.Kepri memiliki tugas tambahan dalam melakukan pengawasan terhadap nelayan dan wilayah kelautan pesisir.

Dalam pelaksanaan tugas dan fungsi tersebut, narasumber juga menjelaskan bahwa masih terdapat banyak kendala di lapangan. Hal ini salah satunya karena kewenangan pemprov terlalu luas sementara SDM yang dimiliki oleh Dinas Kelautan dan Perikanan Provinsi Kepri juga sangat terbatas untuk menangani permasalahan yang menyangkut kelautan dan nelayan. Namun karena memang sudah diperintahkan oleh undang-undang, Pemprov tetap berkoordinasi dengan pemerintah kabupaten/kota untuk mendukung hal tersebut.

Istilah kewenangan atau yang dalam bahasa Inggris dikenal dengan kata "authority" dan sering diidentikkan dengan istilah kekuasaan. Menurut KBBI online, kata kewenangan dipersamakan dengan asal katanya, yaitu "wewenang". Kewenangan dapat pula didefinisikan sebagai "hak dan kekuasaan untuk bertindak, kekuasaan membuat keputusan, memerintah dan melimpahkan tanggung jawab kepada orang/badan lain". Berbeda dengan definisi sebagaimana telah dijabarkan dalam KBBI, kamus hukum (Black Law Dictionary) memberikan arti kewenangan yang lebih luas lagi, dimana kewenangan tidak hanya bicara tentang kekuasaan, akan tetapi dapat pula diartikan sebagai dasar untuk melaksanakan serta menegakkan aturan hukum yang mengandung perintah, dasdar untuk memutuskan, serta pelaksanaan untuk melakukan pengawasan sesuai yuridiksinya.

Dalam konteks HTN dan hukum administrasi Negara (HAN), wewenang merupakan hal yang sangat penting. Hal ini dikarenakan wewenang mengandung "hak dan kewajiban". Selain itu, wewenang juga dideskripsikan sebagai kekuasaan hukum (rechtskracht). Menurut pandangan Nurcholis, suatu kewenangan juga dapat berupa pelaksanan (implementasi) dari kebijakan umum, yang umumnya dilaksanakan melalui petunjuk pelaksanaan maupun petunjuk teknis. Sehingga, dapat dimaknai bahwa pada setiap kebijakan terdapat pelaksanaannya masing-masing. ${ }^{4}$

Sebagai unsur yang membantu Wali Kota dalam menjalankan roda pemerintahan di Kota Tanjungpinang, terkait urusan perikanan dilaksanakan oleh salah satu perangkat Daerah, yaitu Dinas Pertanian Pangan dan Perikanan.

\footnotetext{
${ }^{4}$ Maria Farida Indrati Soeprapto, Ilmu Perundang-undangan, Dasar-dasar dan Pembentukannya, Cet ke-5.Yogyakarta:
} Kanisius IKAPI, 2002. Hlm. 167. 
Sebagaimana kita ketahui, bahwa dengan adanya penataan dan penyederhaan SOTK, maka nomenklatur dinas tersebut telah beberapakali mengalami perubahan nomenklatur, dimana sebelumnya masih bergabung dengan Dinas Kelautan. Namun karena UU No.32 Tahun 2004 tentang Pemerintahan Daerah telah dicabut dengan UU No.23 Tahun 2014, maka nomenklatur kelautan telah dihapuskan. Hal ini juga sejalan dengan hasil wawancara yang telah peneliti lakukan dengan para narasumber yaitu Kepala Bidang Kelautan Dinas Kelautan dan Perikanan Provinsi Kepulauan Riau, Kepala Dinas Pertanian Pangan dan Perikanan serta Kepala Bidang Organisasi dan Tata Laksana Kota Tanjungpinang yang menyebutkan bahwa perubahan nomenklatur tersebut dapat dilihat dalam Perda No. 11 Tahun 2016 tentang pembentukan dan susunan perangkat daerah. Data ini peneliti peroleh berdasarkan hasil wawancara dengan Kepala Bagian organisasi dan Tata Laksana Pemko Tanjungpinang yang pada intinya menyatakan bahwa setiap perangkat daerah yang ada di Tanjungpinang telah dibentuk berdasarkan perintah peraturan perundang-undangan, khususnya PP No. 18 Tahun 2016 tentang Perangkat Daerah. Dimana sebelum dilakukan penetapan melalui peraturan daerah, bagian organisasi melakukan analisis dan kajian beban tugas terlebih dahulu untuk selanjutnya menetapkan tipologi dari tiaptiap dinas maupun badan daerah. Khusus untuk dinas pertanian pangan dan perikanan Kota Tg.Pinang merupakan gabungan dari 2 (dua) dinas yaitu dinas Pertanian Pangan dan juga Dinas Perikanan, karena sejak berlakunya UU No. 23 Tahun 2014 tentang Pemerintahan Daerah, kewenangan pemerintah Kota Tanjungpinang telah dialihkan kepada pemerintah provinsi Kepri, sehingga Dinas Kelautan telah dihapus. DP3 juga telah ditetapkan sebagai dinas dengan Tipologi A dalam Perda No. 11 Tahun 2006 tentang Pembentukan dan Susunan Perangkat Daerah. ${ }^{5}$

Untuk dapat menjalankan tugas dan fungsinya dengan baik, tentunya Dinas Pertanian Pangan dan Perikanan wajib memahami sejauh mana kewenangan yang dimiliki dalam melakukan pembinaan dan pengawasan terhadap nelayan. Wewenang adalah sesuatu yang sangat penting dalam kajian HAN, karena berkaitan dengan pertanggung jawaban hukum dan penggunaan kewenangan tertentu. Prajudi Atmosudirdjo berpendapat bahwa Kewenangan adalah "Kekuasaan formal, kekuasaan yang berasal dari Kekuasaan Legislatif (diberikan oleh Undang-Undang) atau dari Kekuasaan Eksekutif/Administratif."

Jika dilihat dari pembagian urusan kewenangan pemerintah daerah kabupaten maupun kota sebagaimana diatur dalam lampiran UU No. 23 Tahun 2014 tentunya sangat terbatas dan sedikit sekali, yaitu hanya memiliki kewenangan dalam bidang perikanan tangkap dan perikanan budidaya. Adapun bentuk kewenangan perikanan tangkap juga terbatas hanya 2 (dua) saja, yaitu pemberdaayaan nelayan kecil dan Pengelolaan dan penyelenggaraan tempat pelelangan ikan. Sementara itu, dari bidang budidaya juga terbatas pada 3 (tiga) hal saja yang meliputi Penerbitan izin usaha perikanan (IUP) di bidang pembudidayaan ikan yang usahanya berada dalam 1 (satu) wilayah daerah kabupaten atau kota, Pemberdayaan usaha kecil pembudidayaan ikan, dan Pengelolaan pembudidaya ikan.

Pelaksanaan kewenangan tersebut telah diperkuat dengan hasil wawancara yang peneliti lakukan pada Dinas Pertanian Pangan dan Perikanan, terutama melalui Kepala Bidang Perikanan yaitu Bapak Catri Jintar yang menjelaskan bahwa Bidang Perikanan yang ada pada DP3 membawahi 3 (tiga) seksi, yaitu:

a. Kepala Seksi yaitu Kasi Perikanan Tangkap yang dijabat oleh Ibu Siti Marhamah;

b. Kasi Perikanan Budi Daya, dijabat oleh Bapak Jefri Raimono; dan

c. Kasi Pemberdayaan Usaha Kecil Perikanan, yang dijabat oleh Ibu Yuli Poliana

Hal ini tentu saja membatasi ruangan gerak pemda kabupaten/kota dalam menangani masalah yang dihadapi nelayan di daerahnya seperti Hampir setiap tahun terjadi penangkapan ikan tanpa izin (illegal fishing), kematian nelayan yang diakibatnya kecelakan pada saat melaut, minimnya upah buruh nelayan serta masih adanya praktik pinjaman bagi nelayan yang dilakukan oleh pengusaha perikanan dan belum terdaftarnya sebagian besar nelayan dalam program asuransi nelayan.

Dari hasil observasi yang peneliti lakukan ke beberapa daerah pesisir tempat tinggal nelayan, buruh nelayan dan keluarga nelayan. Meskipun kewenangan yang dimiliki Dinas Pertanian Pangan dan Perikanan lebih sedikit, namun upaya perlindungan dan pembinaan yang dilakukan oleh dinas terkait sedapat mungkin dilakukan secara maksimal setiap tahun. Sebagi contoh, hasil observasi yang peneliti peroleh bentuk kegiatan yang dilakukan petugas meliputi pembinaan dan pemberdayaan usaha perikanan, pengolahan kerupuk, penyediaan sarana dan prasarana perikanan, penyediaan sarana/prasarana peralatan tangkap dan pengembangan SDM teknologi perikanan. Kegiatan tersebut dilakukan secara rutin setiap tahunnya, namun tetap berbasis anggaran dan ketersediaan dana dari APBD.

Selain itu, sejak berlakunya UU No.23 Tahun 2014 yang mengatur tentang pembagian urusan kewenangan pemerintahan, baik pusat provinsi maupun daerah kabupaten maupun kota. Narasumber Ahadi juga menguraikan bahwa dengan adanya uu tersebut sebenarnya kewenangan yang dimiliki Pemko Tanjungpinang dalam melaksanakan pembinaan dan pengawasan terhadap nelayan sangat terbatas dan sebagian besar telah ditarik ke pusat dan provinsi. Namun, pemko tidak bisa melangkahi kewenangan yang telah diatur dalam peraturan perundang-undangan.

${ }^{5}$ Berdasarkan hasil wawancara dengan Kepala Bagian Organisasi dan Tata Laksana Pemko Tanjungpinang, pada tanggal 16 Maret 2020. 
Menurut hasil analisis peneliti, jika dikaitkan dengan teori kewenangan yang dikemukakan oleh Steenbeek bahwa terdapat 2 (dua) cara organ pemerintah memperoleh atau mendapatkan kewenangan, yaitu melalui:

1. "atribusi"; dan

2. "delegasi".

Atribusi umumnya berkaitan dengan penyerahan kewenangan yang baru, sementara delegasi terkait dengan pelimpahan terhadap wewenang yang telah diperoleh sebelumnya oleh organ yang telah memperoleh wewenang secara atributif kepada organ lain. Sehingga adanya kewenangan delegasi tentu harus didahului oleh kewenangan atribusi. Menurut Steenbeek, kedua dasar kewenangan tersebut di atas lah yang dapat digunakan sebagai teori / dasar dalam melakukan analisis terhadap kewenangan yang dimiliki oleh aparatur negara dalam menjalankan atau melaksanakan kewenangannya. Lebih lanjut, Steenberk berpendapat bahwa kewenangan Atribusi adalah wewenang yang diperoleh untuk membuat suatu keputusan / besluit, yang bersumber langsung dari undang-undang atau undangundang dasar. Atribusi juga dapat dipahami sebagai suatu cara sah/legal untuk memperoleh atau mendapatkan wewenang pemerintahan.

Lebih lanjut, kewenangan delegasi berarti "penyerahan wewenang untuk membuat besluit oleh pejabat pemerintahan atau yang dikenal dengan pejabat Tata Usaha Negara kepada pihak lain tersebut". Kata penyerahan dimaknai sebagai perpindahan tanggungjawab dari orang yang memberikan delegasi (delegans) kepada orang yang menerima delegasi tersebut (delegetaris).

Pada prinsipnya, suatu delegasi harus memenuhi beberapa persyaratan yang meliputi:

1. Harus Definitive.

Maksudnya adalah orang yang memberikan delegasi (delegans) tidak dapat menggunakan lagi wewenang yang telah dilimpahkan kepada penerima delegasi (delegataris).

2. Dilaksanakan sesuai dengan undang-undang.

Hal ini berarti, delegasi hanya dapat dilakukan apabila diperintahkan dalam suatu peraturan perundang-undangan.

3. Tidak dapat diberikan kepada bawahan.

Maksudnya adalah, dalam konteks yang berkaitan dengan hierarki yang terkait dengan kepegawaian, tidak diperbolehkan adanya delegasi.

4. Wajib memberi Penjelasan atau keterangan.

Maksudnya adalah, delegasi memiliki kewenangan untuk meminta keterangan atau penjelasan terkait peiaksanaan dari wewenang tersebut.

5. Merupakan peraturan kebijakan (beleidsregel).

Artinya adalah "delegasi memberikan petunjuk atau instruksi terhadap penggunaan atas wewenang tersebut". ${ }^{6}$

Berkenaan dengan hal tersebut, maka dapat diperoleh simpulan bahwa kewenangan yang dimiliki oleh Pemko Tanjung Pinang melalui Dinas Pertanian Pangan dan Perikanan dalam melakukan pembinaan terhadap nelayan dan kelautan pesisir di wilayah Kota Tanjungpinang, dari 7 (tujuh) suburusan pemerintahan di bidang kelautan dan perikanan yang dapat dilaksanakan oleh pemerintah pusat, provinsi dan pemerintah daerah kabupaten maupun kota yang telah ditetapkan dalam Lampiran UU tentang Pemda yang meliputi:

a. Kelautan, pesisir dan pulau-pulau kecil;

b. Perikanan Tangkap;

c. Perikanan Budidaya;

d. Pengawasan Sumber Daya Kelautan dan Perikanan;

e. Pengolahan dan Pemasaran;

f. Karantina Ikan, Pengendalian Mutu dan Keamanan Hasil Perikanan; dan

g. Pengembangan SDM Masyarakat Kelautan dan Perikanan.

Dinas Pertanian Pangan dan Perikanan Kota Tanjungpinang hanya memiliki 2 (dua) kewenangan saja, yaitu pada suburusan Perikanan Tangkap dan Perikanan Budidaya karena telah ditetapkan dalam UU No. 23 Tahun 2014 Tentang Pemda. Hal ini juga telah sesuai dengan teori kewenangan sebagaimana dikemukakan oleh Steenbeek, bahwa kewenangan tersebut diperoleh berdasarkan atribusi dari UU Pemda tersebut.

${ }^{6}$ Sawit dan Sumiono dalam Rachmad Safa'at, 1998, "Perlindungan Hukum Hak Adat Kelautan dalam Pengelolaan Sumberdaya Perikanan: Studi Kasus Nelayan Masangan di Kedung Cowek - Surabaya,” Tesis Magister Program Studi Ilmu Lingkungan, Pascasarjana Universitas Indonesia, Depok 


\section{Hambatan Yang Dihadapi Dinas Pertanian Pangan Dan Perikanan Kota Tanjungpinang Dalam Melakukan Pembinaan Nelayan Dan Pengawasan Kelautan Pesisir Pasca Berlakunya Undang-Undang Nomor 23 Tahun 2014}

Meskipun dalam pelaksanaan tugas dan kewenangannya telah diatur dan dijamin dalam peraturan perundangundangan, khususnya UU Pemda, pada prakteknya Dinas Pertanian Pangan dan Perikanan Kota Tanjungpinang (DP3) juga mengalami beberapa hambatan. Dalam kamus besar bahasa Indonesia (KBBI), hambatan memiliki kesamaan pengertian dengan kata "kendala", yaitu segala sesuatu yang bertujuan untuk melemahkan serta menghalangi tujuan yang hendak dicapai. ${ }^{7}$ Dari hasil observasi, wawancara serta studi dokumen yang peneliti lakukan di lapangan, bahwa peneliti diperoleh hasil bahwa pembagian urusan kewenangan pemerintahan dalam bidang perikanan yang telah dibatasi untuk dapat dilaksanakan oleh pemerintah kabupaten/kota belum sepenuhnya efektif dilaksanakan. Hal ini juga didukung oleh hasil tanya jawab dengan narasumber. Setiap hambatan yang mengakibatnya tidak efektifnya aturan tersebut dapat dianalisis berdasarkan teori Efektivitas Hukum yang dikemukakan oleh Soerjono Soekanto. Adapun faktor-faktor tersebut meliputi faktor hukumnya (undang-undang), faktor penegak hukum yang menjalankan uu tersebut, faktor pendukung berupa sarana maupun prasana, faktor masyarakatnya dan juga faktor kebudayaan.

\section{Faktor hukumnya sendiri (undang-undang)}

Menurut pendapat Soerjono Soekanto, undang-undang merupakan faktor utama yang sangat mempengaruhi suatu penegakan hukum. Adapun yang dimaksudkan sebagai undang-undang (dalam arti materiil) merupakan suatu peraturan berbentuk tertulis yang berlaku secara umum dan dibuat oleh pejabat yang berwenang baik di tingkat pusat maupun pejabat daerah secara sah. Dengan demikian, undang-undang tersebut meliputi setiap peraturan tingkat pusat yang berlaku untuk seluruh warga negara maupun kelompok atau golongan tertentu saja, serta aturan yang berlaku umum pada sebagian wilayah NKRI. Selain itu juga termasuk peraturan setempat yang hanya berlaku pada daerah tertentu saja. ${ }^{8}$

Adapun yang dimaksud dengan faktor hukum yang dapat dikaji sebagai indicator keberhasilan Dinas P3 dalam melaksanakan Pembinaan serta Pengawasan terhadap nelayan di wilayah Kota Tanjungpinang pasca lahirnya UU No.23/2014 merupakan perundang-undangan yang mengatur mengenai kewenangan Dinas Pertanian Pangan dan Perikanan dalam penyelenggaraan urusan pemerintahan di bidang perikanan yang diatur dalam UU No.23 Tahun 2014 Tentang Pemda, khususnya dapat dilihat pada bagian lampiran. Bagian penjelasan umum UU Pemda telah menguraikan bahwa tujuan dari penyelenggaraan sistem pemerintahan daerah adalah untuk melakukan percepatan perwujudan tingkat kesejahteraan masyarakat melalui upaya peningkatan dalam hal pelayanan, peran serta masyarakat dan pemberdayaan serta untuk meningkatkan potensi daya saing daerah. Namun tetap memperhatikan prinsip-prinsip demokrasi, keadilan, kearifan lokal suatu daerah dan keadilan dalam konteks NKRI. Dengan lahirnya UU 23/1024 idealnya diharapkan dapat mendukung efektivitas serta efisiensi penyelenggaraan pemda perlu dengan tetap mengacu pada batasan dan aspek hubungan antara pusat dengan daerah, hubungan antar daerah serta potensi dan tantangan persaingan global.

Akan tetapi, tujuan penyelenggaraan otonomi daerah sebagaimana diharapkan oleh UU No.23 Tahun 2014 tidak selalu mencapai tujuan yang ideal. Dengan dicabutnya UU No.32 Tahun 2004, maka kewenangan pemerintah daerah kabupaten atau kota di bidang kelautan semakin terbatas. Telah terjadi perubahan yang sangat drastic pada sektor kelautan, di mana UU Pemda tidak menyisakan satupun kewenangan kepada kabupaten ataupun kota untuk pengelolaan sumber daya laut. Dari salah satu narasumber yang peneliti wawancarai, yaitu Kepala DP3 Kota Tanjungpinang diperoleh hasil bahwa dalam menjalankan tugas dan fungsinya DP3 mengacu pada lampiran UU No.23 Tahun 2014 yang mengatur tentang pembagian urusan kewenangan pemerintahan, baik pusat provinsi maupun daerah kabupaten maupun kota. Kewenangan yang dimiliki Pemko Tanjungpinang dalam melaksanakan pembinaan dan pengawasan terhadap nelayan sangat terbatas dan sebagian besar telah ditarik ke pusat dan provinsi. ${ }^{9}$

Hal inilah yang menjadikan Dinas Pertanian Pangan dan Perikanan sulit untuk melaksanakan pengawasan serta pembinaan terhadap nelayan-nelayan yang ada di Kota Tanjungpinang, terutama yang mengalami permasalahan dalam memperoleh asuransi nelayan dan kartu nelayan. UU 23/2014 hanya memberikan kewenangan bagi dinas pertanian pangan dan perikanan untuk melakukan pemberdayaan nelayan kecil serta pemberdayaan usaha kecil pembudidayaan ikan. Sementara dalam UU Nomor 7 Tahun 2016 tentang, khususnya dalam Pasal 54 disebutkan bahwa:

(1) Pemerintah Pusat dan Pemerintah Daerah sesuai dengan kewenangannya melakukan pembinaan untuk pengembangan Kelembagaan yang telah terbentuk.

\footnotetext{
${ }^{7}$ Lihat KBBI dalam jaringan.

${ }^{8}$ https://nasional.sindonews.com/berita/1357500/18/menantikan-pp-kewenangan-laut, diakses pada tanggal 17 Februari

${ }^{9}$ Berdasarkan hasil wawancara dengan Bapak Ahadi, Kepala Dinas Pertanian Pangan dan Perikanan Kota Tanjungpinang.
} 2019. 
(2) Dalam hal Kelembagaan sebagaimana dimaksud pada ayat (1) belum terbentuk, Pemerintah Pusat dan Pemerintah Daerah sesuai dengan kewenangannya berkewajiban mendorong dan memfasilitasi terbentuknya Kelembagaan.

Selanjutnya, adapun bentuk kewenangan terhadap pembinaan nelayan sebagaimana dimaksud dalam Pasal 54 tersebut di atas, dijabarkan dalam Pasal 55 UU 7/2016, yaitu dapat berupa pembentukan "pranata sosial berdasarkan budaya kelompok nelayan setempat, kelompok Nelayan, kelompok usaha bersama, kelompok Pembudidaya Ikan, dan kelompok pengolahan dan pemasaran hasil Perikanan". Sementara, berdasarkan hasil wawancara yang peneliti lakukan terhadap masyarakat nelayan, isteri atau kelurga nelayan dan juga Dinas Pertanian Pangan dan Perikanan Kota Tg.Pinang bahwa yang dibutuhkan masyarakat nelayan Kota Tanjungpinang tidak hanya berupa kelompok nelayan yang bergabung dalam usaha bersama, kelompok budidaya ikan maupun pengolahan. Namun nelayan lebih membutuhkan pendampingan dari Dinas Pertanian Pangan dan Perikanan untuk diberikan pelatihan terkait pengelolaan hasil perikanan dan strategi pemasaran ikan yang masih jauh di bawah harga ekspor. ${ }^{10}$ Berdasarkan penjelasan dari Kepala Bidang Perikanan, meskipun Pemko Tanjungpinang melalui Dinas P3 ingin melakukan pembinaan terhadap masyarakat nelayan dan kelautan pesisir namun tidak didukung oleh perangkat aturan yang baik, maka tidak akan maksimal.Hal ini disebabkan karena Pemerintah Kota Tanjungpinang juga belum memiliki produk hukum daerah yang mengatur mengenai bentuk pembinaan terhadap nelayan maupun kelautan pesisir. Sehingga sampai saat ini Dinas P3 hanya mengacu pada UU No.23 Tahun 2014, UU No. 31 Tahun 2004 tentang Perikanan sebagaimana telah diubah dengan UU No.45 tahun 2009 dan juga UU No. 7 Tahun 2016. ${ }^{11}$

Sementara terkait pengawasan terhadap pelaksanaan kegiatan Nelayan yang ada di wilayah Kota Tanjungpinang, juga tidak dapat lagi dilaksanakan oleh Dinas P3. Adapun yang melatarbelakangi hal tersebut karena suburusan pengawasan terhadap sumberdaya kelautan serta perikanan merupakan urusan kewenangan yang hanya dapat dilakukan oleh Pem.Pusat dan Pemprov dengan ketentuan sebagai berikut:

a. Pemerintah Pusat melakukan Pengawasan terhadap sumber daya kelautan dan perikanan di atas 12 (dua belas) mil dan strategis nasional dan ruang laut tertentu.

b. Pemerintah Provinsi melakukan Pengawasan sumber daya kelautan dan perikanan sampai dengan 12 mil. ${ }^{12}$

Bagaimanapun juga, meskipun kewenangan pemerintah Kota Tanjungpinang tidak ada sama sekali dalam hal pengawasan, namun tidak dapat dipungkiri bahwa wilayah laut berada di daerah kabupaten/kota. Sehingga pemerintah pusat seharusnya juga memberikan kewenangan kepada pemerintah daerah kabupaten atau kota untuk dapat melakukan pengawasan terhadap nelayan maupun masyarakat pesisir yang ada di wilayahnya.

\section{Faktor Penegak Hukumnya}

Soerjono Soekanto menyatakan bahwa penegak hukum disini merupakan para pihak yang mempunyai kewenangan untuk membentuk serta menerapkan suatu aturan hukum. Adapun para penegak hukum tersebut meliputi: lembaga di bidang Dilkumjakpol (Pengadilan, Kementerian Hukum dan HAM, Kejaksaan dan Kepolisian). Lebih lanjut, dalam pendapatnya Soekanto berpandangan bahwa peran penegak hukum sama pentingnya dengan masyarakat. Sehingga, tidak dapat dipungkiri bahwa apalagi penegak hukum tidak optimal dalam melaksanakan perannya, seringkali menimbulkan konflik kepentingan (status conflict dan conflict of roles). Apabila dalam kenyataan para pihak tidak memahami peranannya, maka akan timbul suatu kesenjangan peranan (role-distance). ${ }^{13}$

Adapun faktor penegak hukum yang dimaksudkan disini adalah Pejabat PPNS yang bertugas melakukan penyidikan terhadap pelanggaran di bidang kelautan dan perikanan. Berdasarkan hasil wawancara serta observasi yang peneliti lakukan di lapangan dengan Kepala Bidang Perikanan, bahwa sampai dengan saat ini Pemerintah Kota Tanjungpinang, terutama Dinas Pertanian dan Perikanan (DP3) belum memiliki pejabat Penyidik Pegawai Negeri Sipil. Sehingga ketika ada pelanggaran yang dilakukan oleh Nelayan kecil, nelayan tradisional, nelayan modern dan nelayan buruh dalam bidang perikanan, belum ada pejabat berwenang yang dapat menindak pelanggar tersebut. Hal ini juga yang kemudian menjadi satu dari beberapa hambatan yang mempengaruhi kinerja Dinas Pertanian Pangan dan Perikanan dalam melakukan pembinaan dan pengawasan terhadap Nelayan di wilayahnya. Tidak adanya PPNS

\footnotetext{
${ }^{10}$ Berdasarkan hasil wawancara dengan Isteri Nelayan di Kecamatan Tanjungpinang Kota.

11 Berdasarkan hasil wawancara dengan Kepala Bidang Perikanan Dinas Pertanian Pangan dan Perikanan Kota Tanjungpinang.

${ }^{12}$ Yelli Meivi Dapu. Implikasi UU No. 23 Tahun 2014 Terhadap Kewenangan Urusan Pemerintahan Daerah Di Bidang Kelautan dan Perikanan. Lex Et Soeciatis Vol.IV.No.8. Tahun 2016.

13 Achmad Ali. Menguak Teori Hukum (Legal Theory) dan Teori Peradilan (Judicialprudence) Termasuk Interpretasi Undang-Undang (Legisprudence). Jakarta : Kencana. 2009.
} 
tersebut juga diakibatkan dari ditariknya kewenangan Pemerintah Kabupaten/Kota dalam hal pengawasan terhadap nelayan dan kelautan pesisir. Sehingga hal ini merupakan salah satu implikasi dari keberadaan UU No. 23 Tahun 2014 pada Dinas Pertanian Pangan dan Perikanan. Selain faktor PPNS, meskipun dalam ketentuan peraturan perundangundangan telah diatur apa saja yang menjadi kewenangan pemerintah Daerah Kota Tanjungpinang dalam melakukan pembinaan serta pemberdayaan terhadap Nelayan, namun apabila kewenangan tersebut tidak dilaksanakan sepenuhnya juga tidak dikenai suatu sanksi administratif. Hal ini menjadi alasan kuat sebagian penegak hukum dalam bidang perikanan di Tanjungpinang.

\section{Faktor Sarana atau Fasilitas Pendukung}

Efektifnya peran penegak hukum juga sangat dipengaruhi oleh sarana maupun prasana pendukungnya. Tanpa didukung oleh sarana maupun fasilitas tertentu, tentu saja proses penegakan hukum tidak dapat dilaksanakan dengan baik sesuai dengan harapan pembentukan suatu aturan (undang-undang). Adapun bentuk sarana maupun fasilitas pendukung tersebut meliputi SDM berlatar belakang pendidikan serta keterampilan yang baik, organisasi yang baik, peralatan yang memadai, sumber pendanaan yang cukup, dan lain sebagainya. Apabila keseluruhan hal tersebut tidak terpenuhi, penegakan aturan hukum yang ingin dicapai sesuai dengan tujuannya akan mustahil dilakukan. Faktor sarana maupun fasilitas pendukung juga merupakan salah satu hal yang menjadi hambatan bagi Dinas Pertanian Pangan dan Perikanan Kota Tanjungpinang dalam melaksanakan kewenangan pembinaan terhadap nelayan dan masyarakat pesisir. Hal ini pun dibuktikan dari hasil wawancara dengan narasumber, yaitu Kepala Dinas P3 bahwa bahwa selama ini kegiatan pembinaan kepada Nelayan baik tradisional, kecil maupun modern sudah berjalan cukup baik. Akan tetapi masih terdapat kendala dan hambatan berupa sarana serta prasarana yang sangat terbatas serta tidak adanya lagi kewenangan pemerintah kota untuk melakukan pengawasan terhadap nelayan yang mengalami kendala melaut karena sejak 0-12 mil laut merupakan kewenangan dari pemerintah provinsi. Sehingga kadang pegawai yang menerima laporan dari nelayan tidak dapat langsung menindaklajuti laporan yang masuk ke dinas. Meskipun kewenangan pemko sudah dibatasi oleh UU Pemda, dalam hal terjadi permasalahan di lapangan Dinas Pertanian Pangan dan Perikanan akan tetap menyampaikan kepada Dinas Kelautan dan Perikanan Provinsi melalui surat dan koordinasi langsung. Selain itu, hambatan dari segi sarana prasana juga meliputi:

a. Kurangnya sumber daya manusia, terutama kelompok jabatan fungsional penyuluh perikanan.

Hal ini sejalan dengan hasil wawancara peneliti dengan Kepala Bidang Dinas Pertanian Pangan dan Perikanan Kota Tg.Pinang, Menurutnya, saat ini DP3 belum memiliki tenaga fungsional, baik fungsional di bidang pertanian pangan maupun fungsional perikanan. Dari bagan struktrur organisasi Dinas P3, juga yang peneliti ketahui belum ada tampak struktur dari tenaga fungsional tersebut. Padahal menurut Catri Jintar, peran fungsional perikanan seharusnya sangat penting untuk menunjang pelaksanaan tugas dan fungsi DP3 untuk dapat turun langsung ke lapangan sesuai dengan jobdesk nya. Sebelum kewenangan pengawasan di bidang kelautan di tarik ke pemprov dan pusat, DP3 memiliki tenaga fungsional. Namun, sejak berlakunya UU No.23/2014 fungsional tersebut telah ditarik ke pemprov dan pusat, karena dalam struktur organisasi DP3 tidak ada lagi bidang yang membawahi Kelautan.

b. Terbatasnya Kewenangan Pelaksanaan Bimbingan Teknis Kepada Nelayan Oleh Dinas Pertanian Pangan dan Pertanian.

Pasca peralihan sebagian kewenangan di bidang kelautan dan perikanan, juga berpengaruh pada program kerja maupun kegiatan rutin yang dilaksanakan oleh Pemerintah Daerah Kabupaten/Kota, termasuk Dinas Pertanian Pangan dan Perikanan Tg.Pinang. Dari hasil wawancara dan observasi yang peneliti lakukan dengan Kepala Seksi Perikanan Tangkap Dinas P3 yaitu Ibu Siti Marhamah, bahwa sejak tahun 2016, kegiatan rutin yang dilakukan oleh Bidang Perikanan adalah pengadaan sarana maupun fasilitas penangkapan ikan serta pengadaan sarana prasaranan perikanan saja. Sedangkan untuk kegiatan berupa pembinaan dan pengawasan yang dilakukan melalui Bimbingan pengawasan hampir tidak pernah dilakukan oleh DP3. Hal ini seharusnya dilakukan oleh Pemerintah Pusat, sesuai dengan lampiran UU Pemda yang mengatur tentang pembagian urusan kewenangan antara pemerintah pusat, pemerintah provinsi serta pemerintah kab/kota. Dengan demikian, sangat tidak bisa dipungkiri bahwa DP3 semakin terbatas dalam memberikan pembinaan pengawasan bagi masyarakat nelayan.

\section{Faktor Masyarakat}

Tempat berlakunya atau diterapkannya suatu aturan maupun Penegakan hukum adalah berasal dari masyarakat. Karena salah satu fungsi hukum adalah untuk mewujudkan ketentraman, keadilan dan ketertiban dalam suatu masyarakat. Dengan demikian, dapat disimpulkan bahwa masyarakat sangat mempengaruhi penegakan hukum. Adapun beberapa contoh masalah yang sering mempengaruhi perilaku penegakan hukum yang tertib atau sebaliknya adalah sebagai berikut:

a. masyarakat tidak menyadari atau mengetahui sepenuhnya bahwa hak mereka telah dilanggar; 
b. masyarakat tidak menyadari atau mendapat informasi bahwa ada tindakan maupun beberapa upaya hukum yang dilakukan oleh penegak hukum untuk melindungi kepentingan masyarakat tersebut; dan/atau

c. masyarakat tidak memiliki kemampuan atau kesanggupan dalam memanfaatkan upaya hukum yang diakibatkan oleh faktor tertentu seperti faktor ekonomi, sosial, politik atau psikologis. ${ }^{14}$

Terhadap hambatan yang dihadapi oleh Dinas Pertanian Pangan dan Perikanan Kota Tanjungpinang dalam melakukan pembinaan dan pengawasan terhadap nelayan di wilayah kerjanya, hambatan tersebut salah satunya juga berasal dari masyarakat nelayan itu sendiri. Mengapa demikian? Dari hasil pengumpulan data serta informasi yang peneliti lakukan kepada perwakilan masyarakat nelayan yang peneliti anggap paling komprehensif, yaitu Buruh Nelayan dan Nelayan Kecil hampir rata-rata menguraikan bahwa terhadap hak apa saja yang seharusnya dapat diperoleh oleh nelayan dalam hal melakukan aktivitas melaut tidak selalu diketahui oleh para Nelayan, khususnya yang berada di daerah Kecamatan Tanjungpinang Kota, dan Kecamatan Tanjungpinang Barat. Hal ini sering kali terjadi, dimana nelayan lebih bersifat pasif. Kecuali apabila ada petugas yang turun ke lapangan untuk melakukan kegiatan pengawasan dan pemberdayaan yang sifatnya tidak menentu, barulah nelayan akan menyampaikan keluh kesahnya kepada petugas. Secara tidak langsung, hal ini juga mempengaruhi Dinas P3 untuk bergerak dalam memberikan perlindungan dalam bentuk pembinaan kepada Nelayan.

Selain daripada kondisi tersebut, dari hasil penjelasan Kepala Seksi perikanan tangkap dan kasi perikanan budidaya, bahwa bisa saja hal ini disebabkan karena memang masyarakat nelayan sudah terbiasa dengan pola hanya pada saat mengalami masalah saja baru melapor ke Pemerintah Daerah. Contohnya saja, ketika mengalami kendala $\mathrm{BBM}$, kendala dalam pengurusan identitas kartu nelayan maupun dalam mengurus asuransi kematian atau bantuan dari pemerintah ketika ada nelayan maupun keluarganya yang mengalami kecelakaan kerja. ${ }^{15}$

\section{Faktor Kebudayaan}

Faktor yang menjadi indicator dalam mengetahui hambatan yang terjadi dalam penegakan suatu hukum adalah Faktor Kebudayaan. Budaya hukum pada dasarnya meliputi seluruh nilai yang mendasari berlakunya suatu hukum, nilai yang berhubungan dengan konsep apa yang dinilai baik maupun yang bernilai tidak baik. Dari hasil penelitian yang peneliti lakukan, bahwa terdapat faktor kebudayaan masyarakat nelayan yang mempengaruhinya. Meskipun sesungguhnya pemerintah daerah tidak lagi memiliki kewenangan dalam melakukan pengawasan terhadap nelayan dan juga masyarakat pesisir, namun Dinas P3 masih memiliki kewajiban untuk pembinaan kelembagaan nelayan serta melakukan pemberdayaan nelayan kecil. Akan tetapi, dari hasil wawancara dan observasi dengan kepala Seksi Perikanan Tangkap dan Kepala Seksi Perikanan Budidaya serta Kasi Pemberdayaan Nelayan, bahwa adanya pola kebudayaan masyarakat nelayan yang masih mengharapkan pelatihan yang dapat membantu nelayan dalam memperoleh pendapatan secara instan atau lebih cepat tanpa membutuhkan waktu yang panjang. Hal ini dikarenakan sebagian besar nelayan pada umumnya bisa dengan cepat memperoleh penghasilan ketika sudah turun ke laut dan menjual hasilnya ke Tekong maupun dijual secara langsung ke pasar.Selain itu, dari Dinas P3 sendiri juga terdapat hambatan atau tantangan tersendiri dalam melaksanakan tugas dan kewajibannya dalam melakukan pengawasan kepada Nelayan di wilayah Kota Tanjungpinang.

Dimana pasca lahirnya UU No. 23 Tahun 2014, memang kewenangan dalam hal pengawasan sektor kelautan dan pesisir sudah beralih ke Pemprov maupun pemerintah pusat. Sehingga, apabila ada laporan maupun pengaduan dari nelayan terkait kendala dalam kegiatan penangkapan ikan maupun terdapat permasalahan yang membutuhkan penanganan dari pemerintah daerah, Dinas P3 tidak berani untuk mengambil alih kewenangan pengawasan tersebut. Karena dari segi kewenangan berdasarkan ketentuan peraturan perundang-undangan, memang harus dilakukan oleh Pemprov. Budaya ini pada akhirnya juga mengakibatkan saling tunggu menunggu untuk menindaklanjuti keluhan dari masyarakat nelayan dan sedikit memperlambat pelayanan yang ada.

\section{Solusi Yang Dapat Diberikan Kepada Dinas Pertanian Pangan Dan Perikanan Kota Tanjungpinang Terhadap Hambatan Yang Dihadapi Dalam Melakukan Pembinaan Nelayan Dan Pengawasan Kelautan Pesisir Dimasa Yang Akan Datang}

Terhadap setiap hambatan, kendala maupun tantangan hendaknya diberikan penyelesaian maupun solusi. Dalam KBBI, dimaknai sebagai "penyelesaian, jalan keluar, atau pun pemecahan masalah". Dengan adanya solusi diharapkan mampu mempermudah jalannya pelaksanaan dari suatu tugas maupun hal yang ingin dicapai. Terkait hambatan yang dialami atau dihadapi oleh Dinas Pertanian Pangan dan Pertanian Kota Tanjungpinang, peneliti memberikan solusi sebagai berikut:

\section{${ }^{14}$ Ibid, Hlm.8.}

15 Berdasarkan hasil wawancara dengan Kepala Seksi Perikanan Tangkap Dinas Pertanian Pangan dan Perikanan Kota Tanjungpinang 


\section{Faktor Hukumnya (Undang-Undang)}

Pemerintah tingkat pusat maupun pemerintah tingkat Daerah memiliki peran yang sangat penting dalam mendukung dan meningkatkan kesejahteraan masyarakatnya tanpa terkecuali termasuk nelayan dan masyarakat pesisir. Dengan adanya pembagian urusan kewenangan, tentunya diharapkan dapat memperdekat jangkauan pelayanan kepada masyarakat, karena selama ini konsep sentralisasi dianggap tidak mampu menjawab seutuhnya permasalahan yang ada di berbagai daerah di Indonesia. Untuk memberikan dasar kewenangan dalam hal pembinaan dan pengawasan nelayan, Negara telah menjamin dan melegalisasi melalui UU No. 23 Tahun 2014 tentang Pemerintahan Daerah. Sebagai konsekuensi dari adanya otonomi daerah otomasit berdampak pada sistem pemerintahan yang bersifat desentralisasi, Pada prinsipnya, desentralisasi juga bertujuan untuk mempermudah adnya koordinasi terkait kekuasaan serta penyelanggaraan pemerintahan yang dapat mengakomodir kepentingan bangsa Indonesia yang terbagi dalam beberapa wilayah yang terpisah-pisah. Salah satunya adalah dengan adanya daerah kepulauan yang luas seperti halnya Kota Tg.Pinang, sangat dibutuhkan adanya peran Pemda Kab/Kota dalam hal pembinaan dan pengawasan terhadap nelayan yang ada di wilayahnya. Berdasarkan Pasal 12 ayat (3) UU No.23 Tahun 2014, Kelautan Perikanan merupakan urusan pemerintahan yang bersifat pilihan yang dapat dilaksanakan oleh pemerintah Kabupaten/Kota. Namun, jika dibandingkan dengan kewenangan pemkab/pemkot sebagaimana diatur sebelum berlakunya UU Pemda, yaitu dalam lampiran huruf cc PP No. 38 Tahun 2007 tentang Pembagian Urusan Pemerintahan Antar Pemerintah , Pemerintah Daerah Provinsi dan Pemerintah Kabupaten/Kota, kewenangan di sektor kelautan dan perikanan bisa dikatakan sangat luas, yaitu memiliki 7 (tujuh) bidang yang meliputi:

a. bidang kelautan;

b. bidang umum;

c. perikanan tangkap;

d. perikanan budidaya;

e. bid. pengawasan dan pengendalian;

f. bid.pengolahan dan pemasaran; dan

g. serta bidang penyuluhan dan pendidikan.

Jika pelaksanaan kewenangan Dinas Pertanian Pangan dan Perikanan masih mengacu pada UU No.32 Tahun 2004 dan PP No. 38 Tahun 2007 tentu saja peran pemerintah daerah kota Tanjungpinang jauh lebih maksimal dan optimal dalam memberikan pelayanan terhadap nelayan yang ada. Sehingga menurut peneliti, dari segi hukumnya, sebaiknya pemerintah pusat dapat mengevaluasi keterbatasan kewenangan pemda kab/kota di bidang kelautan dan memberikan porsi kepada daerah, meskipun sangat kecil atau hanya dibatasi beberapa mil saja, misalnya 0 (nol) sampai dengan 4 (empat) mil saja. Bentuk evaluasi tersebut bisa dilakukan dengan cara melakukan revisi terhadap pembagian urusan kewenangan pemerintah pusat, pemprov maupun pemkab/pemko. Terutama dalam hal pengawasan dan pengendalian kelautan dan juga penyuluhan dan pendidikan. Dengan adanya pemberian kewenangan tersebut, peneliti sangat yakin bahwa hal ini akan akan membantu pelayanan kepada masyarakat dalam rangka otonomi daerah. Hal ini tentunya juga didasari dari hasil interview yang dilakukan terhadap narasumber dari Dinas Kelautan dan Perikanan Provinsi Kepulauan Riau (DKP Provinsi) dan juga Kadis DP3 yang turut mempertegas bahwa antara pemerintah daerah provinsi maupun kabupaten/kota hanya melaksanakan kewenangan sebatas diatur dalam lampiran UU No. 23 Tahun 2014.

\section{Faktor Penegak Hukumnya}

Adapun solusi yang dapat peneliti berikan terkait terbatasnya jumlah penegak hukum yang bertugas dalam melakukan pembinaan terhadap nelayan yang ada di Kota Tanjungpinang khususnya yang berasal dari Dinas Pertanian Pangan dan Perikanan adalah Pemerintah Provinsi maupun pemerintah pusat dapat menambah jumlah unit pelaksana teknis dari Dinas Kelautan dan Perikanan maupun Kementerian Kelautan dan Perikanan di wilayah Kota Tanjungpinang. Selain itu, belum adanya pejabat penyidik pegawai negeri sipil (PPNS) di bidang kelautan dan perikanan di provinsi Kepulauan Riau juga harus menjadi perhatian pemerintah daerah, terutama Dinas Kelautan dan Perikanan Provinsi untuk dapat mengikutsertakan pegawai yang memiliki pengalaman dan kompetensi yang cukup untuk mengikuti diklat PPNS agar dapat melaksanakan kewenangan pengawasan terhadap setiap orang yang melanggar kebijakan terhadap perlindungan nelayan dan masyarakat pesisir, seperti adanya penggunaan peralatan tangkap perikanan yang berbeda dengan jenis peralatan yang diamanatkan oleh ketentuan peraturan perundangundangan, upaya pencurian ikan, bahkan perbuatan perkelahian antar nelayan yang masih ditemukan oleh sering dilaporkan oleh nelayan yang ada di Kota Tanjungpinang. 


\section{Faktor Sarana maupun Fasilitas Pendukung}

Terbatasnya jumlah sarana maupun prasarana sebagai fasilitas pendukung yang digunakan oleh Dinas Pertanian Pangan dan Perikanan (DP3) Kota Tanjungpinang dalam melaksanakan pembinaan dan pengawasan terhadap nelayan perlu diberikan jalan keluar atau solusi. Jika tidak, hambatan tersebut akan mengakibatkan tidak berjalan aturan hukum yang ditujukan untuk setiap nelayan, baik nelayan kecil, buruh, pengusaha perikanan maupun keluargnya. Salah satu hambatan dari faktor sarana/prasana yang dihadapi adalah tidak adanya tenaga fungsional Penyuluh pada DP3. Dari penjelasan Kepala Bidang Perikanan Bapak Catri Jintar, memang sebelumnya fungsional penyuluh perikanan pernah ada di Kota Tanjungpinang, namun kini sudah ditarik ke pusat dan provinsi setelah berlakunya UU No.23 Tahun 2014. Pengalihan pegawai Dinas Kelautan dan Perikanan Kota Tanjungpinang pada waktu iitu dilakukan sekitar tahun 2016, sejak UU Pemda mulai diberlakukan secara efektif. Sesungguhnya, keberadaan fungsional penyuluh perikanan tentunya akan dapat mendukung pelaksanaan pembinaan bagi nelayan maupun keluarganya secara berkala tanpa harus menunggu adanya arahan dari pemerintah pusat maupun provinsi. Ini merupakan solusi yang harus segera dilakukan oleh pemerintah daerah. Jika dilihat dari PP 38/2007, bidang Penyuluh dan kegiatan pelatihan memiliki beberapa fungsi yang menonjol, yaitu:

1. Melaksanakan kebijakan terkait pembinaan dan penyelenggaraan diklat fungsional, teknis, keahlian, manajemen dan kepemimpinan bidang kelautan dan perikanan;

2. Melaksanakan kegiatan penyuluhan kelautan dan perikanan; dan

3. Melaksanakan kebijakan akreditasi dan sertifikasi diklat bidang kelautan dan perikanan.

Solusi ini juga merupakan salah satu masukan dari narasumber dari Dinas Pertanian Pangan dan Perikanan, yaitu Bapak Jefri Raimano selaku Kasi Perikanan Budidaya. Dimana berdasarkan hasil wawancara dengan Bapak Jefri diperoleh hasil bahwa pada satu satu tugas dan fungsinya, seksi perikanan budidaya berharap agar pemerintah daerah dan pemerintah pusat dapat mendukung dan menambah sumber daya manusia yang menguasai perikanan terutama tenaga fungsional yang sudah mengikuti pendidikan dan pelatihan dengan keahlian yang cukup agar dapat memberikan pembekalan-pembekalan melalui kegiatan penyuluhan, sosialisasi, bimbingan teknis dan juga kunjungan langsung kepada nelayan melalui kerjasama dengan RT, Lurah, Camat serta bantuan ketua Himpunan Nelayan Nasional Indonesia Cabang Tanjungpinang. Disamping itu, dari hasil wawancara dengan perwakilan nelayan peneliti juga memperoleh informasi bahwa masyarakat nelayan sangat berharap besar agar Pemerintah Daerah dapat memberikan kegiatan penyuluhan yang tidak hanya bersifat formalitas dan hanya sekedar berupa penyampaian materimateri terkait perikanan saja, namun para nelayan juga menginginkan agar penyuluhan tersebut juga disertai pendampingan secara berkala terhadap praktek ilmu yang disampaikan melalui pelatihan, dan waktu pelaksanaannya juga sebaiknya tidak hanya 1 (satu) kali dalam 1 (satu) tahun, namun secara berkesinambungan sampai nelayan benarbenar mandiri.Sehingga target peningkatan sektor usaha perikanan baik tangkap maupun budidaya yang diharapkan oleh pemerintah dapat terealisasi, begitu juga dengan harapan nelayan dan komunitasnya. ${ }^{16}$

Selain perlu adanya penambahan dan tersedianya penyuluh perikanan, hambatan dari segi prasarana berupa terbatasnya kegiatan pembinaan dan pendidikan bagi nelayan dan terbatasnya penyediaan sarana maupun fasilitas perikanan tangkap, sarana prasarana perikan budidaya dan pengembangan sumber daya manusia yang dilaksanakan oleh Dinas P3 juga seharusnya diberikan solusi dengan cara menambahkan alokasi anggaraan pendapatan dan belanja daerah bagi Dinas P3, agar setiap program kerja yang dilakukan juga bisa lebih maksimal dan tidak terbatas hanya sekali saja dilaksanakan. Paling tidak pengadaaan sarana maupun prasarana perikanan juga sebaiknya dilakukan bersinergi dengan pemerintah pusat dan pemerintah provinsi, sehingga dapat menjangkau semua nelayan terutama yang memiliki kondisi ekonomi lemah dan tergolong tidak mampu.

\section{Faktor Masyarakat}

Permasalahan maupun kendala (hambatan) yang dihadapi oleh Dinas Pertanian Pangan dan Perikanan dalam melakukan pembinaan dan pengawasan terhadap nelayanyang juga diakibatkan oleh faktor masyarakat, harus dituntaskan secara cepat dan tepat, khususnya terhadap nelayan kecil. Hal tersebut bertujuan agar dimaksudkan agar setiap nelayan kecil memperoleh haknya, terutama dalam hal perlindungan hukum dari pemerintah daerah setempat maupun pemerintah pusat sesuai dengan kewenangannya berdasarkan amanat dari Pasal 27 ayat (2) UUDNRI Tahun 1945, yang berbunyi:

\footnotetext{
“tiap-tiap warga negara berhak atas pekerjaan dan penghidupan yang layak bagi kemanusiaan.”
} 
Berbicara mengenai nelayan yang ada di Kota Tg.Pinang, minimnya peran serta nelayan serta keaktifan masyarakat nelayan dalam mendaftarkan diri dalam kepesertaan asuransi nelayan atau asuransi perikanan yang diberikan oleh pemerintah pusat juga menghambat pelaksanaan tugas Dinas P3 dalam membina nelayan. Hal ini dikarenakan, meskipun penganggaran terhadap program perlindungan nelayan dalam bentuk asuransi dibebankan pada APBN, namun pemerintah daerah Kota Tanjungpinang juga diberi tanggungjawab untuk melakukan pendataan terhadap nelayan kecil maupun nelayan tradisional yang akan didaftarkan pada asuransi tersebut. Berdasarkan hasil wawancara dengan nelayan dan petugas dari UPT Kementerian Kelautan dan Perikanan Cabang Tanjungpinang, bahwa nelayan sulit sekali melengkapi administrasi terkait data dukung yang diperlukan untuk kepentingan mereka sendiri. Padahal petugas dari Dinas P3 juga sudah menginformasikan beberapa hak nelayan yang meliputi : "pemberian Asuransi nelayan, litigasi terhadap kecelakaan nelayan dilaut, pemberitahuan keadaan cuaca secara simultan kepada nelayan, serta informasi terkait keanggotaan nelayan dalam kelompok maupun jaringan Himpunan Nelayan Seluruh Indonesia (HSNI)". ${ }^{17}$

Untuk mengatasi rendahnya kesadaran masyarakat nelayan tersebut, Pemerintah Daerah, khususnya Dinas P3 maupun UPT Kementerian Kelautan dan Perikanan yang ada di Tanjungpinang harus melakukan sosialisasi maupun gerakan penyadaran kepada nelayan dengan intensitas yang lebih tinggi. Bentuk penyadaran tersebut berkaitan dengan pentingnya partisipasi nelayan untuk memiliki kartu identitas, kartu tanda nelayan, dan terdaftar sebagai peserta asuransi nelayan. Upaya tersebut jika bisa dilakukan melalui pendekatan dengan nelayan senior yang cukup dituakan di perkampungan nelayan yang ada, sekaligus memberi contoh serta perbandingan terkait dampak positif atau keuntungan yang diperoleh nelayan dengan menjadi peserta asuransi nelayan (asnel). Sebagai contoh, jika ada salah satu nelayan yang mengalami kecelakaan saat menangkap ikan di laut atau bahkan meninggal dunia sekalipun, dengan memiliki asuransi nelayan, maka pemerintah akan memberikan kompensasi berupa uang yang tidak hanya dapat digunakan untuk berobat namun dapat digunakan sebagai bekal hidup dan modal usaha bagi keluarga nelayan yang ditinggalkan. Bentuk Perlindungan yang wajib dilakukan terhadap nelayan kecil dalam kegiatan usaha penangkapan ikan tentunya sangat berpengaruh terhadap kelangsungan kehidupan para nelayan di Kota Tg.Pinang. Selain solusi sebagaimana tersebut di atas, Dinas Pertanian Pangan dan Perikanan juga perlu melakukan kemudahan terhadap akses nelayan dalam memperoleh bantuan dari pusat maupun pemda. Solusi ini juga merupakan salah satu usulan yang dikemukakan oleh oleh narasumber yang berasal dari Asuransi Jasindo Kota Tanjungpinang, yang pada intinya dalam proses pemberian asuransi nelayan dilaksanakan oleh perusahaan asuransi ini merupakan BUMN yang ditunjuk sebagai pihak penyelenggara asuransi nelayan di Kota Tanjungpinang.

Kendala dari segi keterbatasan informasi yang diperoleh nelayan terhadap askses informasi maupun penggunaan teknologi perikanan juga seharusnya lebih diperhatikan oleh pemerintah daerah, meskipun berdasarkan hasil wawancara yang peneliti lakukan dengan Kasi Pemberdaayaan Usaha Kecil Perikanan, yaitu Ibu Yuli Polianan bahwa Dinas P3 telah melakukan beberapa program kegiatan, salah satunya adalah melalui kegiatan pengembangan sumber daya manusia serta penguasaan teknologi. Kegiatan tersebut dilaksanakan pada tahun 2013 dan tahun 2018. Artinya, sepanjang tahun 2013 sampai dengan saat ini tahun 2020, kegiatan tersebut baru dilakukan sebanyak 2 (dua) kali. Pelaksanan kegiatan tersebut seharusnya bisa dilakukan minimal 1 (satu) kali dalam setahun, karena teknologi idealnya selalu diperbaharui dan berkembang setiap tahunnya. Sehingga para nelayan yang ada di Kota Tanjungpinang lebih up to date dalam penguasaan tekhnologi di bidang perikanan dan memudahkan dalam mendukung aktivitasnya sehari-hari, khususnya apabila dilakukan pada musim hujan atau saat terjadi badai atau gelombang yang cukup tinggi dan berbahaya.

\section{Faktor Kebudayaan}

Budaya saling tunggu menunggu untuk melaksanakan pembinaan dan pengawasan terhadap nelayan oleh Dinas P3 sejatinya berpotensi untuk menghambat pelaksanaan perlindungan nelayan di wilayah Kota Tanjungpinang. Hal ini wajib diatasi dengan membangun budaya kerja yang professional, aukuntabel dan sinergis antara pengambil keputusan, khususnya antara Dinas Kelautan dan Perikanan Provinsi Kepulauan Riau, UPT Kementerian Kelautan dan Perikanan serta DP3 Kota Tg,Pinang. Berdasarkan hasil wawancara dengan Kepala Dinas P3, bahwa dengan beralihnya kewenangan kewenangan Pemda kabupaten maupun kota dalam hal kelautan sejak berlakunya UU No.23 Tahun 2014, seharusnya antara pemerintah pusat, provinsi maupun Dinas P3 sudah mengetahui sejauh mana batasan kewenangan masing-masing. Sehingga setiap pengaduan atau laporan yang diberikan oleh masyarakat nelayat yang menyangkut dengan aktivitas nelayan harus segera ditindaklanjuti tanpa harus "saling tunggu".

Selain itu, sebaiknya para stakeholder tersebut dapat duduk bersama untuk mengatasi ritme budaya kerja yang berpotensi untuk memperlambat salah satu bentuk pelayanan masyarakat tersebut, karena sejatinya itulah tujuan dari lahirnya desentralisasi atau otonomi daerah. Sehingga meskipun Dinas P3 memiliki kewenangan yang sangat terbatas,

${ }^{17}$ Berdasarkan hasil wawancara dengan UPT Kementerian Kelautan dan Perikanan Provinsi Kepri, 
namun juga dapat pro aktif untuk berkoordinasi sesering mungkin secara berjenjang, melalui Dinas Kelautan dan Perikanan Provinsi Kepri selanjutnya kepada Kementerian Kelautan dan Perikanan Republik Indonesia.

\section{SIMPULAN}

berikut:

Mengacu pada rumusan masalah dan hasil yang dikaji dalam penelitian ini, diperoleh kesimpulan sebagai

1. Pasca berlakunya Undang-Undang Nomor 23 Tahun 2014, pelaksanaan kewenangan pembinaan dan pengawasan Nelayan dan kelautan pesisir oleh Dinas Pertanian Pangan dan Perikanan Kota Tanjungpinang berjalan tidak efektif, hal ini dikarenakan undang-undang tersebut telah membatasi kewenangan pengawasan pada 2 (dua) bidang saja. Yaitu Perikanan Tangkap dan Perikanan Budidaya sedangkan kewenangan di bidang kelautan telah dihapus dan ditarik ke Pemerintah Provinsi dan Pemerintah Pusat.

2. Hambatan yang dihadapi Dinas Pertanian Pangan dan Perikanan Kota Tg.Pinang dalam melakukan pembinaan nelayan dan pengawasan kelautan pasca berlakunya Undang-Undang Nomor 23 Tahun 2014 meliputi:

a. Terbatasnya kewenangan pengawasan, pendampingan dan pelatihan terhadap nelayan di pesisir Kota Tanjungpinang.

b. Sulitnya koordinasi antara Dinas Pertanian Pangan dan Perikanan Kota Tanjungpinang dengan Pemerintah Provinsi Kepulauan Riau untuk menangani permasalahan hukum yang dihadapi oleh Nelayan yang ada di wilayah Kota Tanjungpinang.

c. Adanya keterbatasan anggaran dalam melaksanakan bimbingan teknis setiap tahun kepada Nelayan, kelompok nelayan maupun keluarganya.

\section{DAFTAR PUSTAKA}

\section{Buku}

Achmad Ali. Menguak Teori Hukum (Legal Theory) dan Teori Peradilan (Judicialprudence) Termasuk Interpretasi Undang-Undang (Legisprudence). Jakarta : Kencana. 2009.

Kusnadi. Konflik Sosial Nelayan: Kemiskinan Perebutan Sumber Daya Perikanan. Jakarta: PT LKiS Pelangi Aksara, 2002.

Lili Rasjidi dan Ira Thania Rasjidi, Dasar-Dasar Filsafat dan Teori Hukum, PT. Citra Aditya Bakti, Bandung, 2004.

Maria Farida Indrati Soeprapto, Ilmu Perundang-undangan, Dasar-dasar dan Pembentukannya, Cet ke-5.Yogyakarta: Kanisius IKAPI, 2002.

Soerjono Soekanto, Pengantar Penelitian Hukum, Jakarta: UI Press. 1983.

Sugiyono, Metode Penelitian Kuantitatif Kualitatif dan R\&D, Bandung: Alfabeta, 2008.

Syafiie, Inu Kencana. Ilmu Administrasi Publik. Jakarta: PT. Rineka Cipta. 2006.

\section{Peraturan Perundang-undangan}

Undang-Undang Nomor 31 Tahun 2004 tentang Usaha Perikanan sebagaimana telah diubah dengan Undang-Undang Nomor 45 Tahun 2009.

Undang-Undang Nomor 23 Tahun 2014 tentang Pemerintahan Daerah

Undang-Undang Nomor 7 Tahun 2016 tentang Perlindungan dan Pemberdayaan Nelayan, Pembudi Daya Ikan, dan Petambak Garam.

Peraturan Pemerintah Nomor 52 Tahun 2002 tentang Usaha Perikanan

Peraturan Pemerintah Nomor 18 Tahun 2016 tentang Perangkat Daerah

Peraturan Menteri Kelautan dan Perikanan Republik Indonesia Nomor 26/PERMEN-KP/2016 tentang Pedoman Nomenklatur Perangkat Daerah dan Unit Kerja Pada Perangkat Daerah Provinsi dan Kabupaten/Kota Yang Melaksanakan Urusan Pemerintahan Di Bidang Kelautan dan Perikanan

\section{Jurnal Penelitian}

Yelli Meivi Dapu. Implikasi UU No. 23 Tahun 2014 Terhadap Kewenangan Urusan Pemerintahan Daerah Di Bidang Kelautan dan Perikanan. Lex Et Soeciatis Vol.IV.No.8. Tahun 2016.

Sawit dan Sumiono dalam Rachmad Safa'at, 1998, "Perlindungan Hukum Hak Adat Kelautan dalam Pengelolaan Sumberdaya Perikanan: Studi Kasus Nelayan Masangan di Kedung Cowek - Surabaya," Tesis Magister Program Studi Ilmu Lingkungan, Pascasarjana Universitas Indonesia, Depok.

\section{Internet}

https://setkab.go.id/potensi-besar-perikanan-tangkap-indonesia/ diakses tanggal 17 Februari 2019. 
Ampuan Situmeang, Rufinus H. Hutauruk, Winsherly Tan dan Dian Fransisca, Efektivitas Kewenangan Pemerintah Kota Tanjungpinang Di Bidang Kelautan Dan Perikanan Pasca Lahirnya Undang-Undang Pemerintahan Daerah

https://nasional.sindonews.com/berita/1357500/18/menantikan-pp-kewenangan-laut, diakses pada tanggal 17 Februari 2019.

\section{Hasil Wawancara}

Hasil Wawancara dengan Kepala Bidang Perikanan dan Pengawasan pada tanggal 13 Maret 2019.

Hasil Wawancara dengan Kepala Dinas Pertanian Pangan dan Perikanan Kota Tanjungpinang, pada tanggal 12 Januari 2020.

Hasil Wawancara dengan Kepala Bagian Organisasi dan Tata Laksana Pemerintah Kota Tanjungpinang, pada tanggal 16 Maret 2019.

Hasil Wawancara dengan Kepala Bidang Perikana DP3 Kota Tanjungpinang, pada tanggal 18 April 2019.

Hasil Wawancara dengan Kepala Seksi Perikanan Tangkap Dinas Pertanian Pangan dan Perikanan, pada tanggal 20 Mei 2019.

Hasil Wawancara dengan Kepala Seksi Perikanan Budidaya DP3, pada tanggal 17 Mei 2019.

Hasil Wawancara dengan Kepala Seksi Perikanan Pemberdayaan Usaha Kecil Perikanan Dinas Pertanian Pangan dan Perikanan Kota Tanjungpinang. 